\title{
Que ninguém entre aqui se não for geômetra ${ }^{1}$
}

\author{
Rafael Rodrigues de Moraes*
}

Resumo Este artigo é reflexo (e reflexão) de uma trajetória de pesquisa intensa sobre o significado verdadeiro de arquitetura entre textos onde seus contextos se inter-relacionam através dos séculos, realizada como produto de pesquisa sobre a essência do projetar em arquitetura, para o projeto de pesquisa Metodologia de Aprendizagem em Arquitetura e Urbanismo (M.A.A.U.). A relação de significado e a perda de, encontra-se em torno do sentido e do discurso de uma origem, ou arché, no que denominados de arquitetura, onde a geometria torna-se palavra fundamentadora; e uma questão de ordem. A denominada geometria sagrada aparenta designar o verdadeiro significado de ser do arquiteto, como discurso intrínseco à busca de sentido na arquitetura.

Palavras-chave: arquitetura, geometria sagrada, arché.

\section{That no one enters here if it is not geometer}

\begin{abstract}
This paper reflects on (and reflects) an intense research trajectory on the true meaning of architecture between texts where their contexts interrelate through the centuries, carried out as a research product on the essence of designing in architecture, for the design of research Methodology of Learning in Architecture and Urbanism (MAAU). The relation of meaning and the loss of, lies around the sense and the discourse of an origin, or arché, in what denominated of architecture, where the geometry becomes word justifying; and a point of order. The so-called sacred geometry seems to designate the true meaning of being of the architect, as a discourse intrinsic to the search for meaning in architecture.
\end{abstract}

Key words: architecture, sacred geometry, arché.

\section{Nadie de aquí si no es geómetra}

Resumen Este artículo es reflejo (y reflexión) de una trayectoria de investigación intensa sobre el significado verdadero de la arquitectura entre textos donde sus contextos se interrelacionan a través de los siglos, realizada como producto de investigación sobre la esencia del diseño en arquitectura, para el proyecto de investigación Metodología de Aprendizaje en Arquitectura y Urbanismo (MAAU). La relación de significado y la pérdida de, se encuentra en torno al sentido y al discurso de un origen, o arché, en lo que denominados de arquitectura, donde la geometría se convierte en palabra fundamentadora; una cuestión de orden. La denominada geometría sagrada aparenta designar el verdadero significado de ser del arquitecto, como discurso intrínseco a la búsqueda de sentido en la arquitectura.

Palavras clave: arquitectura, geometría sagrada, arché. 
0

processo de projeto do arquiteto apresenta origens filosóficas, como explorado no livro de Brandão (1999). Não se trata da filosofia como pensamento abstrato, mas sim a filosofia aplicada, vivenciada, como nos expressa o filósofo Heidegger. A origem do sentido da Arquitetura é a própria origem semântica da palavra, que em suas raízes demonstram a união das palavras gregas arkhé e tektonicós.

A essência do conhecimento do que é arquitetura é uma busca presente em vários autores da historiografia da teoria da Arquitetura. Segundo Colin (2000, pg.32) o arquiteto grego Vitrúvio teria considerado que em arquitetura há dois aspectos: o quê é significado e aquilo que significa.

Naturalmente os significados são recodificados pelo receptor do signo apresentado, pois seus valores se modificam ao longo do tempo. Por isto um templo dedicado à Zeus pode ser considerado um local sagrado ao grego do século -6, uma blasfêmia ao inquisidor do século 12 ou um local turístico ao humano contemporâneo. Entretanto os valores significantes permanecem inalterados pois são reflexos da "forma amorfa" do qual a materialização de um objeto precede. Esta forma amorfa, já explorada pelo filósofo Flusser, é a comunicação de uma configuração ideal que a torna eterna e possível de imaginá-la a qualquer tempo e em qualquer lugar. (MORAES e SCHUELTER, 2016, pg. 13)

Este artigo explora a busca por esta configuração ideal, pela essência da Arquitetura.

\section{O Geômetra e o Arquiteto}

Se considerarmos, como pressuposto, que a Arquitetura estabelece uma relação recíproca com o estado da arte, é possível definirmos que o trabalho realizado por arquitetos expressam uma relação simétrica entre o contexto sócio-cultural e a obra edificada, definida por Daniel Payot como "mímesis architecturale". Nesta relação mimética o "edifício representa o mundo e torna visível suas leis" e, reciprocamente, "o mundo é construído como um edifício", através do processo de projeto do arquiteto. Como microcosmo e macrocosmo, princípios de polaridades opostas, porém não

*Rafael Rodrigues de Moraes é Arquiteto e Urbanista, professor do Departamento de Arquitetura e Urbanismo da UNIFIL. ORCID: $<$ http://orcid.org/0000-00034311-0536>.

\footnotetext{
1 Ageometrètos mèdeis eisito. A referência é datada posteriormente, nos escritos dos neoplatônicos João Filopono e de Olympiodoro, que viveram no século VI d. C.; e por João Tzetzes, autor bizantino do século XII.
} conflitantes, que se interagem e sintetizam o universo e o espírito de sua época. (BRANDÃO, 1999, pg. 69).

Segundo Brandão (1999) a história da Arquitetura pode-se ser dividida em duas partes:

1. Onde os edifícios imitam o universo, por mimesis;

2. Onde os edifícios expressam uma subjetividade do arquiteto pela sua obra.

Segundo o mesmo autor a primeira é uma analogia mística entre Homem-Deus, entre criador e criatura. A segunda é a analogia entre criatura e suas criações, como Homem- 
Objeto, onde o ser pode determinar o significado dos objetos que cria, determinando sua própria realidade. Em "A verdade", livro grego do sofista Protágoras é dito: "O homem é a medida de todas as coisas, das coisas que são, enquanto são, das coisas que não são, enquanto não são." As duas formas demonstram uma relação mimética, ora com o mundo externo criado por um ser superior, ora com o mundo interno e suas respectivas obras.

Esta relação mimética é definida por Payout (Apud BRANDÃO, 1999) quando este declara que o cosmo é a origem ordenadora e o edifício a representação formal deste universo, onde verdadeiramente encontra-se sua essência, ou Arché, conforme descrito por Brandão (1999). Este autor define a perda de sentido na atual arquitetura, tanto na "tradição do novo" ou o "novo tradicional", referindo-se respectivamente ao moderno e ao pós-moderno.

"O templo representa o mundo; mas o mundo, inversamente, é construído como um templo. Aqui o reenvio é recíproco (...) e o edifício como arqui-tectura, isto é, ordem simétrica, reenvia ao mundo como modelo, isto é harmonia, proporcionalidade universal" (PAYOUT apud BRANDÃO, 1999, pg.33)

Este sistema trata-se de uma dialética análoga entre o estado microcósmico do templo e o ser macrocósmico do universo como um sistema dialético do pensamento em oposição à realização (essência/produto). Percebe-se que quanto mais se tende à realização/construção do produto mais se tende à negação do pensamento e o esquecimento do ser, pois a materialização de um é a negação do outro. Para o filósofo Heidegger o despertar do esquecimento do ser é dirigir-se para dentro do que se chamou posteriormente de Ereignis. Esse caminho é a transcendência do próprio pensamento e a busca pela "verdade do ser", que não pode ser explicado ou transmitido ou questionado, mas deve ser, sobretudo, experimentado. $O$ "esquecimento do ser", segundo Guzoni (1991) "(...) se mostra como uma não pensar na verdade do ser facilmente interpretado como uma negligência do pensamento em voga até hoje" e propõe um despertar-se desse esquecimento como prática essencial do ser. O escritor Ítalo Calvino (1990), identifica um "pesadume inerte do mundo", como se todos tivessem sido transformados em pedra: "(...) como se ninguém pudesse escapar ao olhar inexorável da Medusa". No mito descrito por este autor: Perseu decepa a cabeça da medusa sem se deixar petrificar, "se sustenta sobre o que há de mais leve, (...) e dirige o olhar para aquilo que só pode se revelar por uma visão indireta, por uma imagem capturada no espelho". Então o autor propõe uma leveza de pensamento, não no sentido depreciativo, mas no sentido de transcendência do próprio pensamento, livre da materialidade.

A Arquitetura quando compreendida como experiência não-filosófica, enquanto tektonicós, deve ter em si, uma subjetividade criadora, uma origem em sua fundamentação. Segundo Brandão (1999) a arquitetura deve ter em si, "ligações perigosas" entre arte e filosofia, sem explicitar quais ligações seriam estas. Enquanto Silva (1991) nos classifica arquitetura em dois aspectos: teórica e prática; e determina que a arquitetura só existe, de fato, na obra construída. Se "a filosofia é a reflexão sobre uma experiência não-filosófica" (tradução de "la philosophie est réflexion sur une expérice non-philosophique", segundo Waelhens (1959, p. 6), e essa é próxima da filosofia a ponto de inspirar e se tornar filosofia, ela deve ser o resultado 
de reflexão sobre a própria experimentação prática do ser humano; Desta maneira a arquitetura construída é a experimentação humana, enquanto fenômeno no mundo real e seu discurso sua origem fundamentadora, sem o qual não haveria a materialização do objeto de arquitetura e sequer, o discurso de arquitetura, senão como hipótese.

Em sua etimologia, a palavra arquitetura (de arkhé: origem, começo; tektonicós: carpinteiro, ação de construir, construção) nos orienta o pensamento pelo qual devemos compreende-la. Tem origem na Grécia diante da necessidade de distinguir algumas obras "providas de significado existencial maior que outras, que apresentavam soluções meramente técnicas e pragmáticas", onde através de uma expressão artística e filosófica uma arquitetura se destacava de meras construções, como nos orienta Brandão (1999): “(...) É para nós significativo que ao falar de arte, Palavra, Palavra essencial, a que funda o ser - e não a que banaliza e se publica - Heidegger use a expressão casa, habitação, moradia: a palavra é a morada do ser". Em seguida coloca a Arquitetura como Arte e, portanto, também como Palavra que funda o ser, ao oferecer recanto e segurança ou "morada onde confirmamos nossas certezas". A Habitação deve ser compreendida como o "ser" do ser humano, condição fundamental de sua existência, postulado por Heidegger diante do que ele próprio chama de uma crise do sentido de habitar. A origem da primeira arché se perde na memória humana, na essência e na necessidade (pré-texto) de proteger (pró-tectum, após o teto), abrigar, além de ser essencial na compreensão do que é, verdadeiramente, Arquitetura.

Segundo Valéry (1996), o personagem Sócrates explica sua condição de quasearquiteto: "Graças a uma profunda intenção de construir que inquieta secretamente meu pensamento", onde se declara: "um arquiteto que as circunstâncias não acabaram de formar". Em outro trecho diz ao personagem Fedro: "(...) não há geometria sem a palavra. Sem esta as figuras são acidentais; e não manifestam o poder do espírito, nem o servem", destacando a relevância fundamental da geometria enquanto palavra fundamental. E continua: “(...), os movimentos que geram as figuras, reduzindo-se a atos nitidamente designados por palavras, cada figura é uma proposição que pode compor-se com as outras $(. . .)^{\prime \prime}$, destacando a geometria como uma linguagem não-verbal. Na sequência descreve que o geômetra: "(...) retira-se por algum tempo, das imagens e cede cegamente ao destino que preparam para as palavras as máquinas do espírito (...)". Para o personagem Sócrates, e para Valéry, figuras geométricas são aquelas que "são traçados de movimentos que podemos exprimir em poucas palavras".

Sobre Valery, Guedes (1996) nos conduz para o conceito de Sócrates revisto "admite ser o Anti-Sócrates construtor", pois para Sócrates (o personagem) o mais completo de todos os atos seria o de construir. O Sócrates Sofista (o histórico) poderia ter sido, também, um Sócrates Geômetra.

A Geometria (Geo=terra, mundo / metria=medida; medida do mundo) é a mãe de todas as ciências matemáticas. "Por ser a Geometria uma imagem da estrutura do cosmos, ela pode ser facilmente utilizada como sistema simbólico para a compreensão de várias estruturas do universo". (PENNICK,1980) 
. E este autor a define desse modo:

"A geometria é geralmente incluída na disciplina da matemática numérica; todavia, a matemática numérica, na verdade derivou da geometria, que possui uma ordem muito mais fundamental o que a mera manipulação de números, que é a criação do homem. (...) Dizendo respeito em primeiro lugar às razões e às relações, a expressão da geometria em termos de números pertence a um período posterior do seu desenvolvimento. A complexa geometria do Egito Antigo, que habilitou arquitetos e geômetras a medir o tamanho exato do seu país, estabelecer indicadores geodésicos e erigir vastas estruturas como pirâmides, era uma arte prática que implicava no seu relacionamento com o número". (PENNICK, 1980, p 6-7, grifo do autor)

De fato, embora atualmente a geometria é uma disciplina da matemática, esta antecede a álgebra e fundamenta a matemática. Este formalismo matemático que acompanhou as grandes obras antigas precede de um desejo platônico da busca pela "Ordem e Perfeição", segundo Silva (1991) a Ordem é palavra fundadora do modelo de perfeição denominado de universo. A escola Pitagórica qualificavam que certas relações numéricas (e estas relações embasadas ou descritas em geometria) como Harmônicas (relação das partes em caminho da perfeição). Onde o mesmo autor ainda afirma: "Os pitagóricos intuíram, corretamente, que há, na natureza, não um, mas vários curiosos e admiráveis traçados reguladores, provas da harmonia numérica do cosmos". A concepção pitagórica do número como princípio ordenador de todas as coisas desvenda e demonstra, matemática e geometricamente, a ordem universal. Afinal, "o ilimitado emerge dos limites", conforme já demostrado por Doczi (1990).

A Arquitetura e sua "dança" entre Arte e Filosofia, ao longo dos últimos milênios, demonstra ao olhar mais atento sua relação geométrica com o universo em que habita. A concepção contemporânea da função do arquiteto como mero construtor de edificações (ou às vezes nem isso) denigre a origem do seu ser; o arquiteto designa, constrói princípios, pró-jeta, planeja, gerencia cidades. O arquiteto detém um conhecimento perpétuo transmitido de geração a geração de novos arquitetos desde os gregos (e antes disso) que é o conhecimento do mundo, que é conhecimento do ser, que é o conhecimento de uma ordenação incrível presente em nós, na natureza e na natureza desta. O conhecimento mitificado de um Deus Arquiteto e Geômetra que desenha o mundo com uma das mãos e molda o barro com a outra.

O arquiteto como construtor deve buscar em sua prática a verdadeira essência da arquitetura. A geometria é a "verdade do ser" do "ente" arquiteto. O Geômetra é a transcendência de seu próprio ser. O escritor argentino Borges (1999) determina que há uma transcendência em cada um de nós: "Quem entreviu o universo, quem entreviu os ardentes desígnios do universo não pode pensar num homem (...) mesmo que esse homem seja ele". Esta transcendência do próprio ser, proporcionado pela geometria, é análoga tanto no universo quanto no ser: do microcosmo ao macrocosmo. 
Figura 1 (topo): Deus Criador, geometra, Codex Vindobonensis 2554.Fonte: Acervo de imagens do autor.

Figura 2: Recorte de ponto fundamental no esquema geométrico para a construção de um pentagrama. Fonte: acervo do autor.
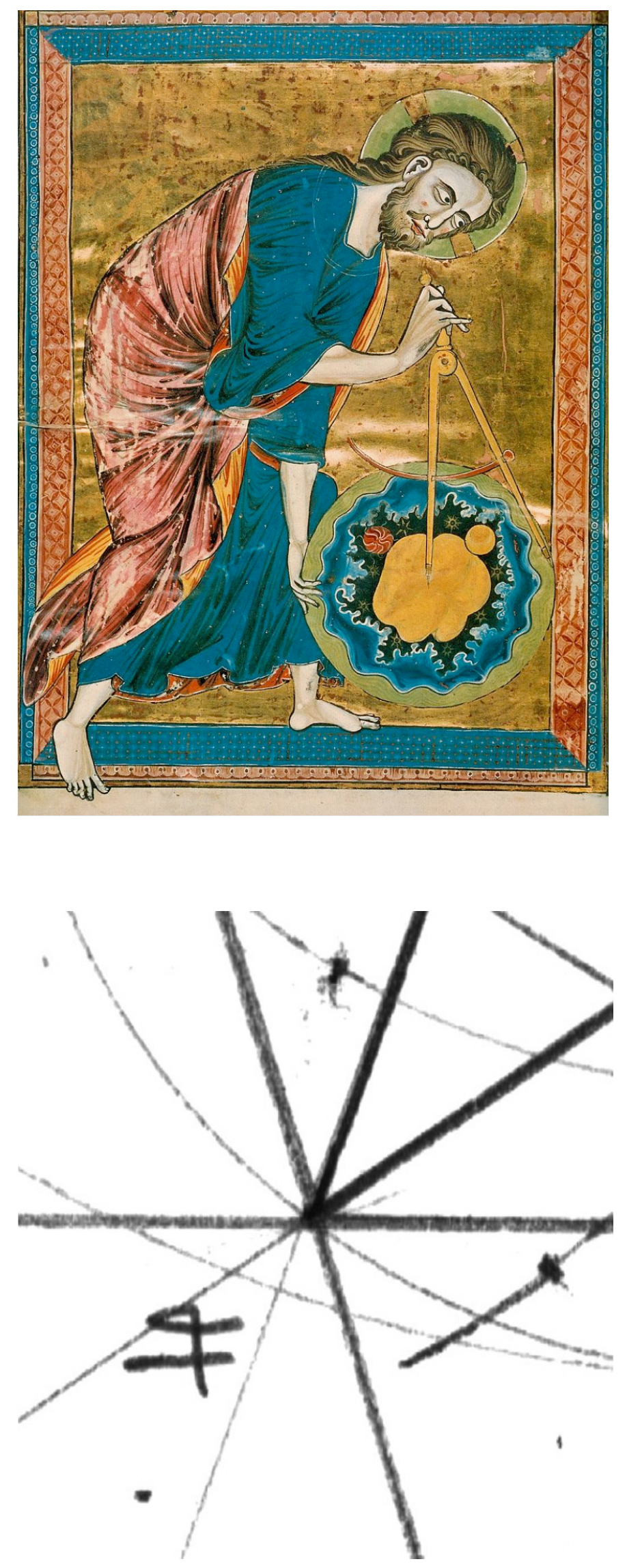
Figura 3 (topo): A verificação da proporção áurea. Fonte: acervo do autor.

Figura 4: $O$ traçado regulador e a proporção áurea. Fonte: Doczi.

\section{A proporção áurea, a seção áurea e a análise tipológica}

Existe uma ordenação na natureza, seja em uma concha ou em um balanço de um pêndulo, em uma flor ou em um gesto de uma mão se abrindo. "Algo infinitamente maior do que nós se revela e, ainda assim, é parte de nós mesmos; o ilimitado emerge dos limites" (DOCZI, 1990).

O segmento áureo é expressa pela fórmula: $A: B=B(A+B)$ no qual a parte menor está para a maior assim como a parte maior está para o todo. Pode ser observado no padrão de crescimento das flores, como margaridas e girassóis, folhas e frutos, no corpo humano e nos organismo animais. Para o filósofo Pitágoras foi natural intuir que todo o Universo é ordenado por relações semelhantes.

Com já mencionado o filósofo grego Protágoras (490a.C.-415 a.C.) considerava que os seres humanos refletiam uma harmonia indissociável ao universo e dizia-se que o corpo humano seria o "homem-medida". Porém o conhecimento da proporção áurea/divina provavelmente é inerente aos gregos, pois ela pode ser identificada em construções como as pirâmides do Egito e os Zigurates na Mesopotâmia, no círculo de pedra de Salisbury denominada de Stonehenge, nos revelando um possível conhecimento universal advindo da observação constante da natureza ou de um conhecimento primordial anterior que fora perpetuado até os dias de hoje.
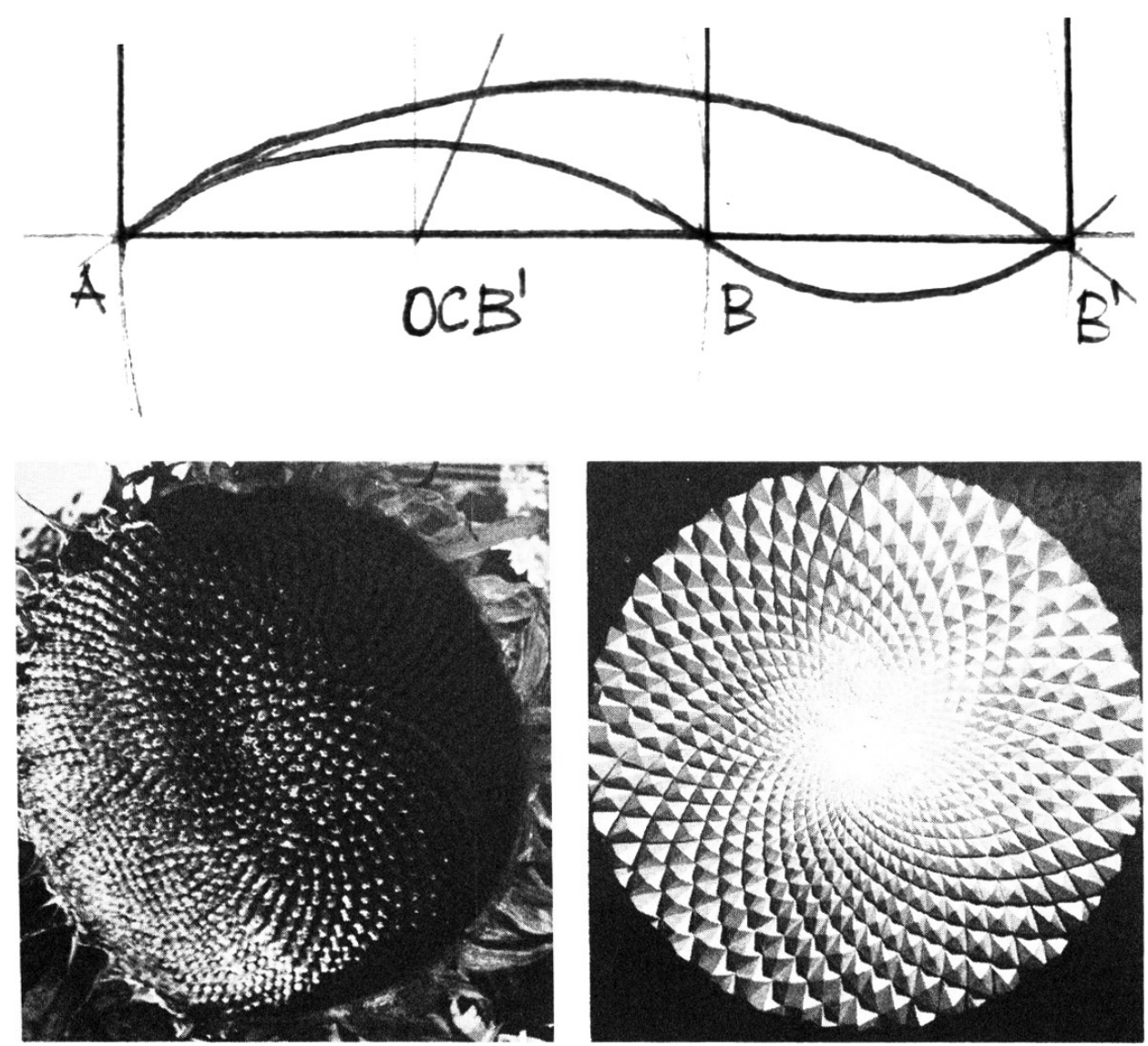
Também nos revela um mundo de ordenação curiosamente bela (ou denominada de) onde o artefato humano é fruto do conhecimento da natureza da própria natureza, expressa magnificamente onde nós expressamos nossas certezas, na morada do ser.

Os estudos de Marco Vitrúvio Polião (80a.C.-15d.C.), arquiteto e escritor romano do séc. I, intitulada De Architetura Libri Decem, sugere que os templos sejam construídos com um discurso análogo ao corpo humano e sua perfeita harmonia intrínseca: "nenhum templo pode ser bem composto sem que se considere alguma proporção ou semelhança, a não ser que tenha exatas proporções, como a dos membros segundo uma figura humana bem constituída" (POLIÃO, 1999, p. 92).

No século XIII, Leonardo Bignollo Fibonacci (1170-1250), matemático italiano responsável por introduzir os número arábicos na Europa com a publicação do livro "Liber Abaci" (Livro do Ábaco) em 1202, propôs uma série de números inteiros onde o próximo é a soma dos dois anteriores como demonstrado na sua famosa série: "1, 2, 3, 5, 8, $13,21,34,55,89,233,377,610,987$, etc..."; Onde a divisão de qualquer número pelo seguinte tende para 0,618 e qualquer número dividido pelo antecessor tende para o número irracional $1,618 \ldots$, conforme a série tende ao infinito, demonstrando a natureza infinita dos números racionais. Desse modo os números irracionais não são apenas uma não-razão, mas estão além dela, infinitos e incomensuráveis.

As catedrais medievais como Chartres, Cantebury, Notre-Dame são "a mais fina flor da arte da geometria sagrada", segundo Pennick (1980). Conforme este mesmo autor as catedrais góticas são as máximas manifestações da "Summa Theologiae" (1265-1273), de São Tomás de Aquino (1225-1274), assim como a "incorporação microscómica do universo criado", unindo através da sua linguagem de composição o conceito do sagrado ao ser humano, através da geometria e do simbolismo.

Novamente a proporção ressurge na Renascença pelo Tratado "De Divina Proportioni" pelo matemático Luca Pacioli (1445-1517), apresentado em Veneza em 1509 e ilustrado por Leonardo DaVinci. A proporção divina é chamada pelo próprio DaVinci de Proporção Áurea em seus estudos posteriores da proporção do corpo humano. A redescoberta das obras de Vitrúvio, influenciou o Renascimento, "após quase um milênio de obscuridade", sendo Miguel Angêlo, Bramante, Vignola e Palladio, arquitetos do período renascentista e insaciáveis estudiosos destas obras (PENNICK, 1980, p. 68).

Os movimentos Barroco e o posterior Art Nouveau era, segundo Pennick (1980), visto pelos puristas como movimentos "degenerados", pela sua ruptura ao cânone da arquitetura clássica e ao detalhe da manipulação do ornamento, mas segundo o autor é muito próximo dos princípios clássicos e da linguagem da geometria.

A geometria é a linguagem não verbal do arquiteto, já predizia le Corbusier, quando este propôs um sistema de medição proporcionada denominada de Modulor (modulo de ouro), realizado após estudos investigativos deste arquiteto sobre a proporção áurea, traçado regulador da Abadia de Chaalis, sobre proporções egípcias e sobre mosaicos bizantinos, em 1948, com medidas idênticas e coincidentes entre eles e a sua proposta de Modulor. (CORBUSIER, 1961, p. 177-197) 

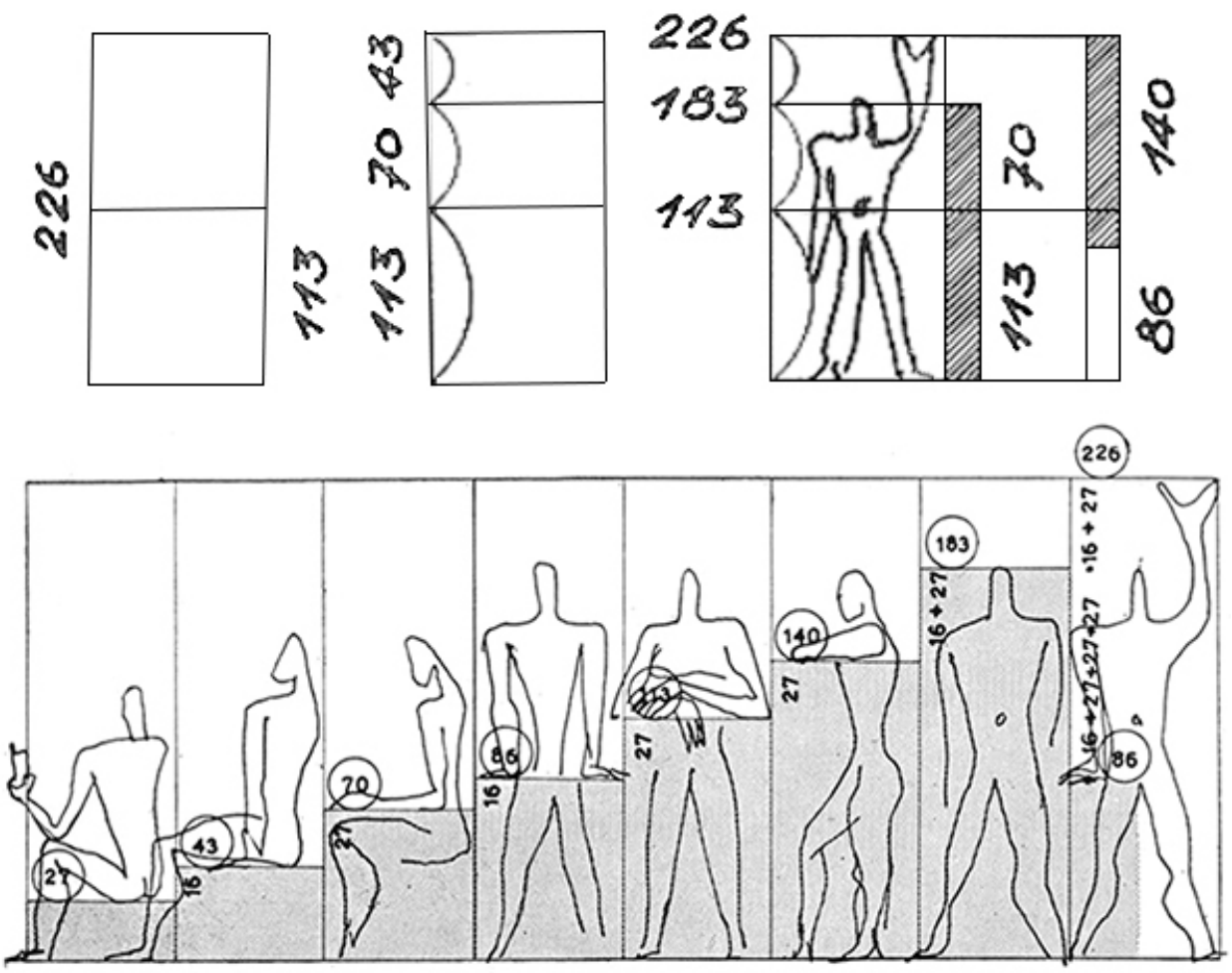

Figura 5: Croquis de Modulo de le Corbusier. Fonte: "Por uma arquitetura" - le Corbusier.
A arquitetura, do qual le Corbusier denominou de "grande arquitetura" confunde-se com a origem da humanidade, sendo "a primeira manifestação do homem criando seu universo", demostrando que todas as épocas utilizaram o traçado regularizador, como princípio de ordenação do pensamento (CORBUSER, 2002, p. 44-47)

Em Rowe (1976) há duas causas da beleza: a Natural e a Costumeira, onde é natural a forma geométrica. Ainda, segundo o autor, há uma relação intensa entre clássico e moderno através da comparação de diagramas analíticos de projetos do arquiteto maneirista Andrea Palladio (1508-1580) e do arquiteto modernista le Corbusier (18871965). Demonstra-se analogias entre o desenvolvimento entre duplas de edificações separadas por aproximadamente 4 séculos como la Rotonda e Ville Savoye e entre Villa Foscari e Villa Stein-de Monzie. Apesar de serem compostas por materiais e sistemas estruturais diferentes a distribuição dos ambientes e a organização geométrica são análogas, como o "piano nobile" de ambas residências. La Rotonda e Ville Savoye, por exemplo, tem inspiração geométrica no arquetípico platônico-aristotélico de abrigo ideal, onde "...talvez em ambos os casos seja a adesão às regras que caducaram". Essas regras, apresentadas nestes tipos ideais de edificações, representam um tipo de planejamento, influenciado pela matemática, como também por valores historicistas.

"Simbolicamente, e no que pode ser chamado de esfera da beleza "costumeira", esses dois grupos de edifícios estão em mundos diferentes. Palladio buscou a clareza completa do plano, a organização mais lúcida dos elementos convencionais baseados na simetria, como a forma de ordem mais memorável e a matemática como a suprema sanção no mundo das formas externas. Em sua própria mente, seu trabalho 
Figura 6: Diagramas de geometria da Casa Vanna-Venturi. Fonte: CLARK \& PAUSE. era essencialmente o da adaptação, a adaptação da antiga casa; e na parte de trás de sua mente sempre foram os grandes salões das Termas Imperial, e edifícios como a villa de Adriano em Tivoli. Ele tem vários esquemas de reconstrução arqueológica de edifícios domésticos gregos e romanos, baseados em Vitruvio e Plínio, e incorporando elementos, que na prática grega e romana teria sido encontrado apenas em edifícios públicos, mas que ele considerava geral. Roma para ele ainda estava viva, e se os antigos haviam adaptado o templo da casa, seu planejamento em larga escala era sem dúvida igualmente reflexivo. O desenvolvimento foi, portanto, menos uma questão de inovação, do que uma extensão de idéias já implícitas" (ROWE, 1976)

A análise tipológica é de extrema importância para compreendermos o pensamento da arquitetura. Quando Montaner (2002) resgata o conceito do "tipo" e "modelo" de Quatremère de Quincy (1832), conforme demosntrado: tipo como idéia platônica e arquetípica em busca de uma forma básica comum; modelo como algo a ser repetido tal qual se apresenta. O conceito da tipologia arquitetônica é utilizado tanto como ferramenta de análise, quanto ferramenta de projeto.

"Nomear o objeto arquitetônico também é um processo do qual a natureza da linguagem é obrigado a tipificar. Tipo significa o ato de pensar em grupos, agrupando objetos por certas semelhanças estruturais inerentes. A arquitetura não é apenas descrita por tipos, também é produzida por meio deles. O arquiteto inicia o projeto a partir do tipo." (MONEO, 1978)

Segundo PIRES a abordagem tipológica decorrente do movimento moderno (1920-1950) segue teorias formais sobre princípios funcionalistas (ou matemáticas, conforme Rowe) sendo diferente no pós-modernismo (anos 1970), quando há a abordagem semiótica.

Já Clark \& Pause (2005) analisam a arquitetura da pós-modernista Casa Vanna-Venturi (1964), de Robert Venturi e Denise Brown e demonstram um processo compositivos inspirados neste mesmo arquetípico geométrico, associados à um partido arquitetônico icônico, segundo mesmas regras de composição geométrica. Ou seja, independe da abordagem, a geometria se apresenta como ferramenta.

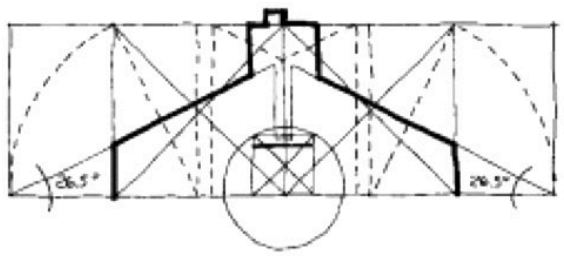
GEOMETRIA DA FACATAPA

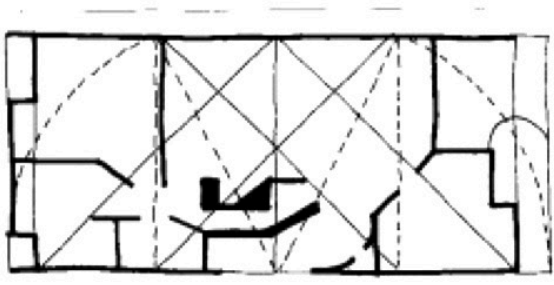

GEDMEThit DA PLANTM

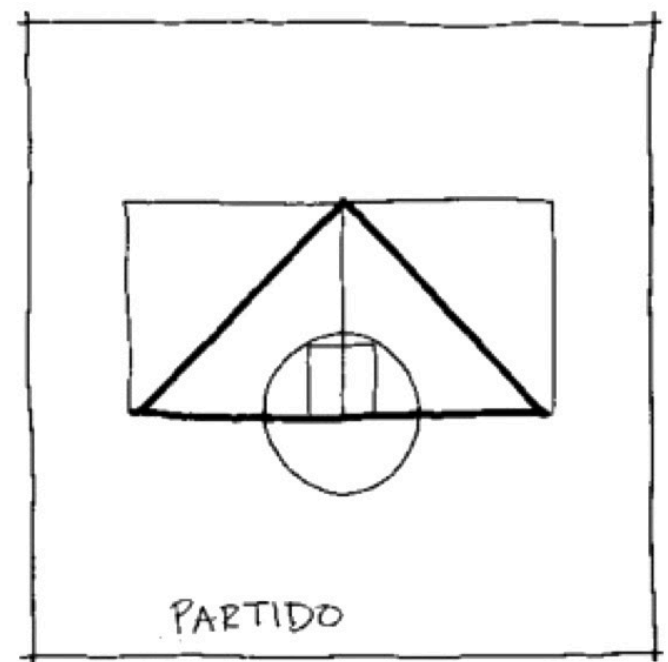




\section{Conclusão}

É importante constatar que, inerente ao movimento estilístico ou período da arquitetura, a geometria é linguagem não-verbal e ferramenta de composição do arquiteto. Em todas as "Grandes Arquiteturas", como escreveria le Corbusier, a geometria é fundamento e palavra de ordem, desde tempos primordiais até o pósmodernismo. Independente se é uma interpretação do universo, do sagrado ou mesmo da interpretação subjetiva do arquiteto, embora pouco usual entre arquitetos contemporâneos.

Quando Heidegger enuncia o fim da filosofia enquanto pensamento e propõe uma filosofia praticada, uma "tarefa para o pensamento" como "última possibilidade" a tornar-se "primeira possibilidade" no processo de renovação do pensamento ("questão do pensamento heideggeriano"). Sua procura pelo "ser" do "ente" mostrou a Filosofia como "fundamento" (arché / princípio) e:

"(...) fundamento é aquilo de onde o ente como tal, em seu tornar-se, passar e permanecer, é aquilo que é e como é, enquanto cognoscível, manipulável e transformável. O Ser como fundamento leva o ente a seu presentar-se adequado. O fundamento manifesta-se como sendo presença. Seu presente consiste em produzir para a presença cada ente que se presenta a seu modo particular. $O$ fundamento, dependendo do tipo da presença, possui o caráter do fundar como causação ôntica do real, como possibilitação transcendental da objetividade dos objetos, como mediação dialética do movimento do espírito absoluto, do processo histórico de produção, como vontade de poder que põe valores". HEIDEGGER (1996)

Se Brandão (1999) anuncia a perda da arché no desenvolvimento da modernidade, faz-nos supor a perda de princípio também na arquitetura, transformada (ou deformada) em mera construção. Segundo este autor, o filósofo Heidegger identifica o mesmo no ser e propõe uma volta para o princípio das coisas, seguida de uma atuação prática deste retorno. Também nos introduz ao conceito do "princípio de todos os princípios" anunciada:

"Toda intuição que originalmente dá (é) uma fonte de direito para o conhecimento; tudo que se oferece originariamente na 'Intuição' (por assim dizer em sua realidade viva) (deve) ser simplesmente recebido como aquilo que se dá, porém, também somente no interior dos limites nos quais se dá...". HEIDEGGER (1996)

O retorno para a prática atual de Arché em Arquitetura (como não-construção) poderia dar-se através do questionamento da "verdade do ser" da arquitetura e pela procura pelo "princípio de todos os princípios" em sua origem fundadora. Em seu princípio e fundamentação encontramos a geometria como palavra de Ordem. Mais que uma "garantia contra o arbitrário" como nos escreveu Le Corbusier em "Vers une Architecture", além do discurso e mais do que mera ferramenta, mas como linguagem não-verbal e anacrônica da Arquitetura. Pois: A geometria é a "verdade do ser" do "ente" arquiteto. O Geômetra é sua transcendência. 


\section{Referências bibliográficas}

BORGES, Jorge L. Obras Completas - Volume I. São Paulo: Ed. Globo, 1999.

BRANDÃO, Carlos A. L. A formação do homem moderno visto através da arquitetura. $2^{a}$ edição. Belo Horizonte: Ed. UFMG, 1999.

CALVINO, Ítalo. Seis propostas para o próximo milênio. São Paulo: Ed. Companhia das Letras, 1990.

CLARK, Roger H. e PAUSE, Michael. Precedents in Architecture - Analytic Diagrams, Formative Ideas, and Partis (Third Edition). New Jersey: John Wiley \& Sons, 2005.

COLIN, Silvio. Uma introdução à arquitetura. Rio de Janeiro. Editora UAPÊ, 2000

CORBUSIER, le. Por uma arquitetura. São Paulo: ed. Perspectiva, 2002

El Modulor: Ensayo sobre una medida armonica a la escala humana applicable universalmente a la arquitectura y a la mecânica. Buenos Aires: Ed. Pseidon, $1961<$ <ttps:// monoskop.org/images/2/21/Corbusier_Le_El_Modulor_2a_ed.pdf> acesso em 13 de maio de 2017

DOCZY, Gyorgy. O Poder dos Limites: harmonias e proporções na natureza, arte e arquitetura. São Paulo: Ed. Mercúrio, 1990.

GUZONI, Alfredo. Protocolo do Seminário Sobre a Conferência "Tempo e Ser". In: HEIDEGGER, Martin. Coleção "Os Pensadores". 4. ed. São Paulo: Nova Cultural, 1991. P. 221-241.

HEIDEGGER, Martin. Conferências e Escritos Filosóficos. São Paulo: Ed. Nova Cultural, 1996.

MONEO, Rafael. On Typology. < https://doarch152spring2015.files.wordpress.com/2015/01/ moneo_on-typology_oppositions.pdf> acesso em 01 de maio de 2016 .

MONTANER, Josep Maria. As formas do século XX. Ed. Gustavo Gili, AS, Barcelona 2002.

MORAES, Rafael R. e SCHUELTER, Kelly I. Uma investigação entre o desenho e o objeto. In.: Revista Terra e Cultura: cadernos de ensino e pesquisa./ Centro Universitário Filadélfia. Londrina, PR, v.1, n. 1. Jun./dez. (1985-). v. 32, n. 6 3, jan./jun.. 2016. P. 13-19.

NICOLAS, Pierre Alexandre. O segredo das catedrais. $1^{\circ}$ edição. São Pauo: Triom, 2001.

PENNICK, Nigel. Geometria Sagrada: Simbolismo e Intenção nas estruturas religiosas. São Paulo. Ed. Pensamento, 1980.

PIRES, Amílcar de Gil . Os conceitos de Tipo e de Modelo em Arquitectura. Acessado em < http://lafis.fa.utl.pt/ciaud/res/paper/CONC-TIPO-MODELO.pdf>

ROWE, Colin. The Mathematics of the Ideal Villa and Other Eassays. < https://www.architectural-review.com/rethink/viewpoints/march-1947-the-mathematics-of-the-ideal-villa-palladio-and-le-corbusier-compared/8604100.article> acesso em 13 de maio de 2017

SILVA, Elvan. A forma e a fórmula: cultura, ideologia e projeto na arquitetura da Renascença. Porto Legre: Ed. SAGRA, 1991.

VALERY, Paul. Eupalinos ou o Arquiteto. São Paulo: Editora 34, 1996.

WAELHENS, Alphonse. Philosophie et non-philosophie. In: Revue Philosophique de Louvain. Troisième série, tome 57, n53,1959. pp. 5-43. doi : 10.3406/phlou.1959.4985. <http:// www.persee.fr/doc/phlou_0035-3841_1959_num_57_53_4985> acesso em 01 de maio de 2016. 